\title{
KELAS DAN POPULASI BAKTERI ICE NUCLEATION ACTIVE PENYEBAB LUKA BEKU PADA DAUN JERUK KEPROK SOE DI DATARAN TINGGI MUTIS
}

\author{
Hildegardis Missa ${ }^{1 \bullet}$, Anselmus Boy Baunsele ${ }^{2}$ \\ ${ }^{1}$ Program Studi Pendidikan Biologi, Fakultas Keguruan dan Ilmu Pendidikan, Universitas Katolik Widya \\ Mandira, Jl. Jend Achmad Yani 50-52 Kupang 85225 , Nusa Tenggara Timur, Indonesia; \\ ${ }^{2}$ Program Studi Pendidikan Kimia, Fakultas Keguruan dan Ilmu Pendidikan, Universitas Katolik Widya \\ Mandira, Jl. Jend Achmad Yani 50-52 Kupang 85225, Nusa Tenggara Timur, Indonesia. \\ `Email korespondens: hildegardismissa17@gmail.com
}

\begin{abstract}
Research on ice nucleation-active bacteria the causal agent of frost injury from tropical areas has not been widely published. The purpose of this study was to determine the population of Ice Nucleation-Active Bacteria on Soe tangerines leaves and the class of Ice Nucleation-Active bacteria based on Ice formation temperatures. The collecting of Soe tangerine leaves used the purpose sampling method. Leaves with frost blotches were collected from three stages at altitudes of 1500, 1800, and 2000 meters above sea level ( $m$ asl). Bacterial isolation was carried out by the spread plate method on Nutrien Agar 2,5\% glycerol (NAG) media. Ice Nucleation activity of the bacteria was determined by the tube nucleation test method. Estimation of INA bacterial population was conducted by the multiple-tube nucleation test with Thomas series .3.3.3. The result showed that the highest INA bacterial population was $6.9 \times 10^{4}$ which was found in leaves samples collected from stations $2000 \mathrm{~m}$ asl, and the lowest population i.e. 5,4x10 on leaf samples from station $1500 \mathrm{~m}$ asl. Based on the temperature of ice formation, it was known that INA bacteria that attack the Soe tangerines leaves Mutis plateau are the INA bacteria class $B$ and $C$.
\end{abstract}

Keywords: Ice Nucleation-Active bacteria, Frost Injury, Ice Nucleation-Active protein class, Soe Tangerine, Mutis plateau.

\begin{abstract}
Abstrak. Penelitian tentang bakteri luka beku dari daerah tropis belum banyak dipublikasikan. Tujuan dari penelitian ini adalah untuk mengetahui populasi bakteri ice nucleation active (INA) pada daun jeruk keprok soe, dan mengetahui kelas bakteri INA berdasarkan suhu pembentukan es. Pengambilan sampel daun jeruk keprok soe menggunakan metode purposive sampling. Daun yang menunjukkan bercak luka beku diambil dari tiga stasiun pada ketinggian $1.500 \mathrm{mdpl}, 1.800 \mathrm{mdpl}$ dan $2.000 \mathrm{mdpl}$. Isolasi bakteri dilakukan dengan metode spread plate pada media NA 2,5\% gliserol (NAG). Aktivitas nukleasi es ditentukan dengan metode tube nucleation test. Estimasi populasi bakteri INA dilakukan dengan metode multiple-tube nucleation test formula Thomas seri 3.3.3. Hasil penelitian menunjukkan bahwa populasi bakteri INA tertinggi adalah sebesar $6,9 \times 10^{4}$ yang ditemukan pada sampel daun jeruk yang dikumpulkan dari stasiun $2.000 \mathrm{~m} \mathrm{dpl}$, dan populasi terendah $5,4 \times 10^{3}$ pada sampel daun dari stasiun $1.500 \mathrm{~m}$ dpl. Berdasarkan suhu pembentukan es, diketahui bahwa bakteri INA yang menyerang daun Jeruk keprok soe yang tumbuh di Dataran Tinggi Mutis adalah bakteri INA kelas protein B dan C.
\end{abstract}

Kata kunci: Bakteri Ice Nucleation, Luka beku, Kelas Protein Ice Nucleation, Jeruk keprok soe, Dataran Tinggi

\section{PENDAHULUAN}

Di Pulau Timor (Indonesia), jeruk keprok (Citrus reticulata Blanco) dikenal dengan nama jeruk keprok soe. Jenis jeruk ini banyak tumbuh di Dataran Tinggi Mutis yang merupakan daerah terbasah dan terdingin di Pulau Timor. Temperatur di Dataran Tinggi Mutis berkisar antara $14^{\circ} \mathrm{C}-$ $29^{\circ} \mathrm{C}$, dan pada kondisi ekstrim dapat turun hingga $9^{\circ} \mathrm{C}$ (Adar et al., 2013). Jeruk keprok soe hanya bisa bertahan hidup dan berbuah selama kemarau panjang dengan suhu 14$29^{\circ} \mathrm{C}$. Namun, sejak tahun 2010 terjadi perubahan iklim yang cukup signifikan di daerah ini. Hujan turun hampir setiap bulan sepanjang tahun, menyebabkan banyak tanaman jeruk keprok soe di Dataran Tinggi Mutis mengalami kerusakan pada kulit, daun dan batang, sehingga menyebabkan sebagian besar tanaman ini mati. Salah satu penyebab kerusakan tersebut adalah luka beku (frost injury) yang ditandai dengan gejala bercak, dapat berwarna coklat, kuning, hitam, daun dengan cincin klorosis yang mengelilinginya (Hardiyanto et al., 2017). Luka beku umumnya teramati muncul di Dataran Tinggi Mutis pada bulan Juli atau Agustus. Pada saat itu, temperatur di tempat ini dapat mencapai nol derajat Celsius dan 
bahkan bisa mencapai $-8^{\circ} \mathrm{C}$ mengakibatkan Jeruk keprok soe sering mengalami luka beku dan pada akhirnya menyebabkan kematian tanaman.

Luka beku disebabkan oleh spesies bakteri ice nucleation active (INA) yang hidup di permukaan daun tanaman di dataran tinggi dengan suhu yang rendah (Rostami et al. 2018). Bakteri INA yang telah ditemukan antara lain Pseudomonas syringae, Pseudomonas viridiflava, Pseudomonas Fluorescens, Erwinia hericola, dan Xantomonas campestris (Atlas n.d.). Bakteri-bakteri ini mampu mengkatalis pembekuan es pada suhu $-1,5^{\circ} \mathrm{C}$ sampai $10^{\circ} \mathrm{C}$, bahkan pada suhu di atas $5^{\circ} \mathrm{C}$, yang dapat menyebabkan terjadinya luka beku di permukaan daun (Minsavage and Stall 2017).

Keberadaan bakteri INA pada permukaan daun mampu meningkatkan kemungkinan terbentuknya luka beku pada suhu di atas $5^{\circ} \mathrm{C}$. (Failor et al. 2017) menyatakan bahwa sebagian dari bakteri INA secara potensial memainkan peranan dalam pembentukan salju, perubahan cuaca, dan pembentukan inti es di awan serta menstimulasi terjadinya hujan. Bakteri INA berpartisipasi dalam siklus biopresipitasi yaitu membantu pembentukan awan dan hujan (Morris et al., 2004). Berdasarkan uraian di atas, perlu dilakukan penelitian keragaman bakteri INA penyebab luka beku pada tanaman jeruk keprok soe di Dataran Tinggi Mutis.

\section{METODE}

\section{Pengambilan Sampel}

Sampel daun jeruk diambil dari Dataran Tinggi Mutis pada tiga titik ketinggian berbeda yaitu: $1.500 \mathrm{~m} \mathrm{dpl}, 1.800$ $\mathrm{m}$ dpl dan $2.000 \mathrm{~m} \mathrm{dpl}$, peta pengambilan sampel tersaji pada gambar 1. Pengambilan sampel dalam penelitian ini menggunakan metode purposive sampling yaitu pengambilan sampel dengan pertimbangan seperti penentuan skala atau scoring keparahan penyakit daun jeruk keprok soe.

Dalam penelitian ini pengambilan sampel tidak menggunakan plot (plotless) artinya sampel diambil berdasarkan tingkat keparahan luka pada daun jeruk keprok soe pada titik ketinggian yang sudah ditentukan.

Bahan tanaman yang diambil yaitu berupa daun sebanyak 5-10 gr, dimasukkan di dalam kantong kertas yang diberi label berisi informasi ketinggian dan sampel tersebut dibawa ke laboratorium dan disimpan dalam lemari pendingin pada suhu $5^{\circ} \mathrm{C}$.

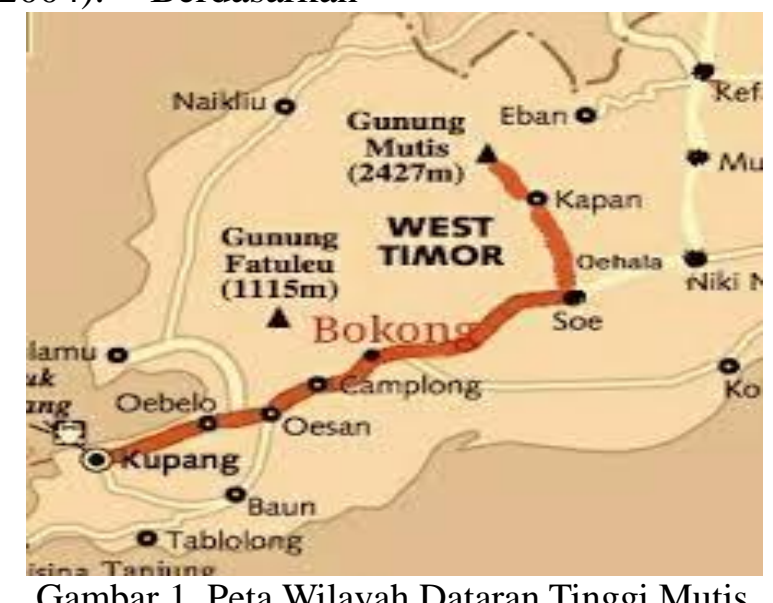

\section{Estimasi dan Populasi Bakteri INA}

Perhitungan populasi bakteri dilakukan dengan metode multiple tube nucleation yaitu suatu metode untuk mengestimasi jumlah inti es dari suspensi bakteri maupun populasi bakteri INA pada bagian tanaman (Murie et al., 2013). Estimasi populasi bakteri INA dilakukan dengan menggunakan 
uji tabung untuk menentukan jumlah bakteri pembentuk inti es yang didasarkan pada jumlah tabung yang membeku pada setiap seri pengenceran (Minsavage and Stall 2017). Suhu optimum yang digunakan untuk uji estimasi populasi bakteri INA adalah $5^{\circ} \mathrm{C}$ hal ini didukung oleh penelitian yang dilakukan oleh (Susilowati, 2018) yaitu pada suhu $5^{\circ} \mathrm{C}$ sudah cukup peka untuk mendeteksi aktivitas pembekuan inti es oleh bakteri INA.

Estimasi populasi dilakukan dengan menggunakan tabung tes berdiameter $18 \mathrm{~mm}$ yang berisi $9 \mathrm{~mL}$ bufer fosfat steril didinginkan pada suhu $-10^{\circ} \mathrm{C}$ selama 30 menit, tabung tersebut dikocok dan semua tabung yang mengalami pembekuan dipisahkan. Tabung yang tidak membeku dihangatkan pada suhu $5^{\circ} \mathrm{C}$. Sampel daun sebanyak $2 \mathrm{~g}$ dihomogenkan dalam $20 \mathrm{~mL}$ bufer fosfat $\mathrm{pH} 7.0$ dan $0,1 \%$ peptone meat, kemudian diambil sebanyak $1 \mathrm{~mL}$ dan dimasukkan dalam tabung reaksi berisi $9 \mathrm{~mL}$ bufer fosfat steril. Selanjutnya dilakukan 3 seri pengenceran yaitu $10^{-1}, 10^{-2}, 10^{-3}$ menggunakan tabung berisi bufer fosfat yang tidak membeku. Setiap seri pengenceran dilakukan sebanyak tiga ulangan sehingga didapatkan pengenceran seri 3 tabung. Setiap tabung berisi bufer fosfat yang tidak membeku dan sampel tumbuhan yang telah dihomogenkan dimasukkan ke dalam circulating alcohol bath selama 10 menit sehingga suhunya mencapai $-3^{\circ} \mathrm{C}$ sampai $-9^{\circ} \mathrm{C}$. Jumlah tabung reaksi yang membeku dihitung untuk setiap pengenceran. Bakteri INA yang ada dipermukaan daun diestimasi dengan cara menghitung jumlah tabung yang membeku pada tiap pengenceran kemudian dicocokkan pada tabel MPN menggunakan formula Thomas seri 3.3.3.

\section{Isolasi Bakteri INA}

Sampel tumbuhan sebanyak $5 \mathrm{~g}$ dipotong dengan ukuran $5 \mathrm{~cm}$ dan dimasukkan dalam tabung erlenmeyer berisi $200 \mathrm{~mL} \mathrm{0,1} \mathrm{M} \mathrm{buffer} \mathrm{fosfat} \mathrm{pH}$ 7,0 dengan
0,1\% pepton (Difco) (Susilowati, et al., 2018). Tabung erlenmeyer yang berisi larutan buffer fosfat dan sampel daun digoyang pada rotary shaker dengan kecepatan $150 \mathrm{rpm}$ selama 2 jam, kemudian Sampel diambil sebanyak $1 \mathrm{~mL}$ dan dimasukkan dalam tabung reaksi berisi $9 \mathrm{~mL}$ akuades steril dan dilakukan 3 seri pengenceran, yaitu $10^{-1}, 10^{-2}$, dan $10^{-3}$. Dari tiap pengenceran diambil sebanyak $0,1 \mathrm{~mL}$ kemudian disebar pada media NA yang mengandung 2,5\% gliserol (NAG) dengan teknik cawan sebar. Masing-masing seri pengenceran disebar pada dua cawan petri, selanjutnya dibungkus dengan kertas dan diinkubasi pada suhu $37^{\circ} \mathrm{C}$ selama 4 x 24 jam dengan posisi terbalik (Missa, 2016).

Koleksi kultur murni diperoleh dari bakteri berbeda yang tumbuh pada media NAG, dipindahkan dengan menggunakan jarum ose dan digoreskan kembali pada media NAG miring yang sudah diberi label yang menunjukan tempat pengambilan sampel, stasiun penelitian, nama peneliti dan nomor isolat. Dalam hal ini simbol huruf A menunjukan tempat penggambilan sampel dengan titik ketinggian $1.500 \mathrm{~m} \mathrm{dpl}$, huruf $\mathrm{B}$ untuk titik ketinggian $1.800 \mathrm{~m} \mathrm{dpl}$, dan huruf $\mathrm{C}$ untuk titik ketinggian $2.000 \mathrm{~m}$ dpl. selanjutnya Huruf $\mathrm{H}$ merupakan huruf pertama nama peneliti, dan No 1 sampai 20 untuk nomor isolat.

\section{Uji Aktivitas Pembentukan Inti Es}

Aktivitas pembentukan inti es dilakukan dengan metode multiple tube nucleation test dengan cara koloni bakteri berumur 4-6 hari pada media agar miring dipindahkan dengan jarum ose dan disuspensikan dalam $400 \mu$ l bufer phospat steril dan diuji aktivitas nukleasi es pada suhu $-5^{\circ} \mathrm{C},-7^{\circ} \mathrm{C}$ dan $-10^{\circ} \mathrm{C}$ menggunakan circulating alcohol bath selama 10 menit. Pengujian dilakukan pada suhu yang berbeda karena berdasarkan aktivitasnya, protein INA terbagi atas tiga kelas utama yaitu kelas $\mathrm{A}$, aktif membentuk inti es pada suhu $-2^{\circ} \mathrm{C}$ hingga $-5^{\circ} \mathrm{C}$, Kelas $\mathrm{B}$, aktif pada suhu $\geq-5^{\circ} \mathrm{C}$ 
hingga $-7^{\circ} \mathrm{C}$ dan Kelas $\mathrm{C}$ aktif pada suhu $\geq-$ $7^{\circ} \mathrm{C}$ hingga $-10^{\circ} \mathrm{C}$ (Rostami et al., 2018) (Minsavage and Stall 2017). Hasil uji positif ditandai jika bufer fosfat yang ditetesi suspensi bakteri membeku dalam waktu 30 detik pada suhu $-5^{\circ} \mathrm{C},-7^{\circ} \mathrm{C}$ dan $-10^{\circ} \mathrm{C}$ dan dapat dianggap bahwa koloni mengandung inti es aktif atau terdapat bakteri INA (Murie et al., 2013).

\section{Karakterisasi Isolat Bakteri INA}

Karakterisasi isolat bakteri dilakukan dengan pengamatan morfologi sel yaitu bentuk dan jenis gram yang dapat dilihat dari hasil pewarnaan gram. Pewarnaan gram ini dilakukan dengan fiksasi yaitu meletakan massa bakteri ke gelas objek, kemudian diteteskan pewarna kristas violet, lugol, alcohol $96 \%$ pada massa bakteri. Selanjutnya massa bakteri dibilas dengan menggunakan safranin, dan diamati bentuk dan jenis gram menggunakan mikroskop (Missa et al., 2020).

\section{HASIL DAN PEMBAHASAN}

\section{Estimasi Populasi Bakteri INA Penyebab Luka Beku (Frost Injury) Pada Daun}

\section{Jeruk keprok soe di Dataran Tinggi Mutis}

Pada penelitian yang dilakukan di masing-masing stasiun pengambilan sampel ditemukan adanya tabung yang menunjukan positif beku, hal ini menunjukan bahwa tabung yang beku mengandung paling sedikit satu inti es. Berdasarkan uji yang dilakukan, pada stasiun pengambilan 1 yaitu $1.500 \mathrm{~m} \mathrm{dpl}$, didapat jumlah tabung positif dengan kombinasi 3-2-2 kemudian dikocok dengan MPN menggunakan formula Thomas seri 3.3.3 dan dilakukan perhitungan menunjukan hasil 5,4 x $10^{3} \mathrm{MPN} /$ gram. Pada stasiun pengambilan 2 yaitu $1.800 \mathrm{~m}$ dpl, didapat jumlah tabung positif beku dengan kombinasi 3-3-3 kemudian dikocok pada tabel MPN menggunakan formula Thomas seri 3.3.3 menunjukan hasil 6,3 x $10^{4} \mathrm{MPN} /$ gram. Pada stasiun pengambilan 3 yaitu $2000 \mathrm{~m} \mathrm{dpl}$, didapat jumlah tabung positif beku dengan kombinasi 3-3-3 kemudian dicocokan dengan tabel MPN menggunakan formula Thomas seri 3.3.3 menunjukan hasil $6,9 \times 10^{4} \mathrm{MPN} / \mathrm{gram}$. (tabel 1). (Susilowati et al., 2018) menyatakan bahwa populasi bakteri INA dapat mencapai $10^{2}-10^{7} \mathrm{sel} / \mathrm{g}$ jaringan tanaman.

Tabel 1. Estimasi populasi bakteri berdasarkan tabel MPN

\begin{tabular}{cccc}
\hline $\begin{array}{c}\text { Stasiun Pengambilan } \\
\text { Sampel ketinggian }\end{array}$ & & $\begin{array}{c}\text { Skala } \\
\text { Bercak }\end{array}$ & \multicolumn{2}{c}{$\begin{array}{c}\text { Populasi bakteri/g sampel } \\
\text { daun }\end{array}$} \\
\cline { 1 - 1 } $1.500 \mathrm{~m} \mathrm{dpl}$ & 1 & $5,4 \times 10^{3}$ \\
$1.800 \mathrm{~m} \mathrm{dpl}$ & 2 & $6,3 \times 10^{4}$ \\
$2000 \mathrm{~m} \mathrm{dpl}$ & 3 & $6,9 \times 10^{4}$
\end{tabular}

Keterangan :

Skala bercak $1=$ luka beku pada permukaan daun $10 \%$

Skala bercak 2 = luka beku pada permukaan daun 11-30\%

Skala bercak 3= luka beku pada permukaan daun 31-50\%

Rata-rata populasi bakteri INA pergram sampel daun jeruk keprok soe di Dataran Tinggi Mutis dikatakan tinggi, jika dibandingkan dengan populasi bakteri INA pergram sampel daun kentang di kecamatan Batur, dataran tinggi Dieng, dengan ketinggian $1800 \mathrm{~m}$ dpl total populasi bakteri INA yang ditemukan adalah 1,44 x $10^{-2}$, pada ketinggian $2000 \mathrm{~m} \mathrm{dpl,} \mathrm{total} \mathrm{populasi}$ bakteri INA yang ditemukan adalah 3,00 x $10^{-3}$ (Rajasa 2015). Perbedaan jumlah populasi bakteri INA tergantung pada 
perbedaan ketinggian tempat, waktu pengambilan sampel, ketersediaan air hujan dan udara. Keberadaan bakteri INA dalam air hujan dan udarah memainkan peran penting dalam proses nukleasi yang diperlukan untuk induksi hujan (STEPHANIE and WATURANGI 2012).

\section{Luka Beku Pada Tanaman Jeruk Keprok Soe Di Dataran Tinggi Mutis}

Analisis luka beku pada daun jeruk keprok soe dilakukan dengan menghitung korelasi antara besarnya bercak luka beku daun yang bervariasi pada tiga stasiun pengambilan sampel dengan menggunakan metode skala atau scoring keparahan penyakit (Manandhar et al. 2008). Dari perhitungan korelasi antar besarnya bercak luka beku pada daun diperoleh skala bercak tertinggi yakni skala 3 dengan luas bercak berkisar $31-50 \%$ sedangkan skala terendah yakni skala 1 dengan luas bercak sekitar $10 \%$. Hasil korelasi antara populasi bakteri
INA dengan skala bercak pada daun tanaman Jeruk keprok soe berdasarkan data pada tabel 1 dianalisis menggunakan SPSS dengan uji Correlation Bevariate disajikan pada tabel 2 .

Uji pearson cotrelation bivariate mengasumsikan bahwa jika nilai $r$ yaitu korelasi $>0,05$ maka terdapat korelasi antara kedua variabel, dan jika nilai sig (1-tailed) < 0,05 maka kedua variabel tersebut memiliki korelasi yang signifikan (Hirano et al., 2008). Hasil uji dari penelitian ini menunjukkan nilai r 0,866 artinya 0,866 > 0,05, maka terdapat korelasi antara kedua variabel, dan nilai signifikan $0,033<0,05$ artinya korelasi antara populasi bakteri dan skala bercak tersebut signifikan. (Govindarajan and Lindow 2006) Menyatakan bahwa jika nilai korelasi berkisar 0,80 sampai 1,000 maka terdapat hubungan yang kuat antara kedua variabel tersebut.

Tabel 2. Analisis Korelasi Estimasi bakteri dengan Skala bercak menggunakan

\begin{tabular}{|c|c|c|c|}
\hline \multicolumn{4}{|c|}{ Uji Corelation bivariate } \\
\hline & & $\begin{array}{c}\text { Populasi } \\
\text { Bakteri/daun jeruk } \\
\text { keprok soe yang } \\
\text { terinfeksi luka beku }\end{array}$ & $\begin{array}{c}\text { Skala Bercak/daun } \\
\text { jeruk keprok soe } \\
\text { yang terinfeksi luka } \\
\text { beku }\end{array}$ \\
\hline \multirow{3}{*}{$\begin{array}{l}\text { Populasi } \\
\text { Bakteri }\end{array}$} & $\begin{array}{l}\text { Pearson } \\
\text { Correlation }\end{array}$ & 1 & .866 \\
\hline & $\begin{array}{l}\text { Sig. (2- } \\
\text { tailed) }\end{array}$ & & .033 \\
\hline & $\mathrm{N}$ & 3 & 3 \\
\hline \multirow{3}{*}{$\begin{array}{l}\text { Skala } \\
\text { Bercak }\end{array}$} & $\begin{array}{l}\text { Pearson } \\
\text { Correlation }\end{array}$ & .866 & 1 \\
\hline & $\begin{array}{l}\text { Sig. (2- } \\
\text { tailed) }\end{array}$ & .033 & \\
\hline & $\mathrm{N}$ & 3 & 3 \\
\hline
\end{tabular}

Isolasi Bakteri Ice Nuclation Active (INA) Daun Jeruk keprok soe Dataran Tinggi Mutis

Sampel daun jeruk keprok soe diambil pada 3 stasiun yang berbeda berdasarkan ketinggian tempat dengan pengulangan 2 kali, dan setiap pengulangan dilakukan 3 kali pengenceran sehingga didapatkan 18 biakan pada media NAG di dalam cawan petri. Dari 18 biakan pada cawan petri, diperoleh 64 isolat disajikan pada tabel 3 .

Pengujian aktivitas nukleasi es 
dilakukan pada 64 isolat yang didapat, dan hasil pengujian aktivitas nukleasi es terhadap seluruh isolat, didapat 8 isolat yang mengalami pembekuan. Hasil pengujian tersaji pada gambar 2 .

Tabel 3. Isolat bakteri yang didapat dari setiap desa

\begin{tabular}{cccc}
\hline $\begin{array}{c}\text { Stasiun } \\
\text { Pengambilan } \\
\text { Sampel }\end{array}$ & $\begin{array}{c}\text { Jumlah } \\
\text { isolat yang } \\
\text { didapat }\end{array}$ & $\begin{array}{c}\text { Jumlah } \\
\text { Isolat yang } \\
\text { membeku }\end{array}$ & $\begin{array}{c}\text { Kode } \\
\text { Isolat }\end{array}$ \\
\hline $1.500 \mathrm{~m} \mathrm{dpl}$ & 21 & 2 & AH1 \\
& & 2 & AH6 \\
$1.800 \mathrm{~m} \mathrm{dpl}$ & 23 & \multirow{3}{*}{4} & $\mathrm{BH} 3$ \\
& & & $\mathrm{CH} 2$ \\
$2.000 \mathrm{~m} \mathrm{dpl}$ & 20 & & $\mathrm{CH3}$ \\
& & & $\mathrm{CH5}$ \\
& & & $\mathrm{CH7}$ \\
\hline
\end{tabular}
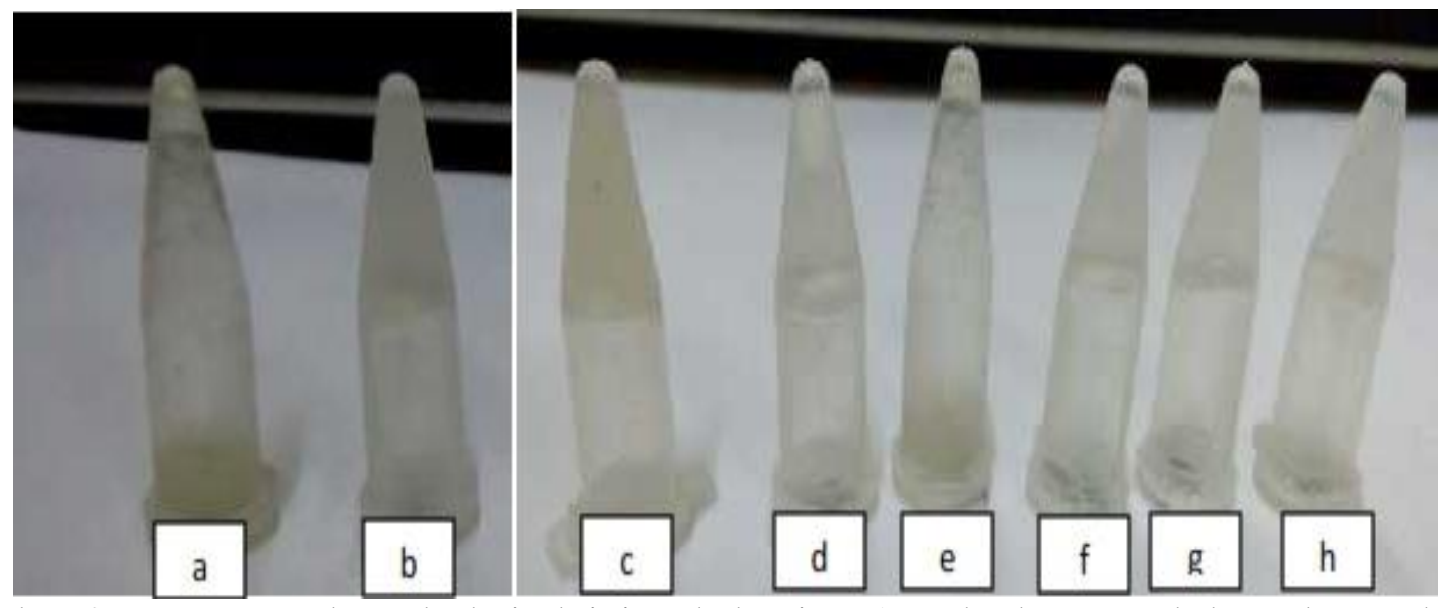

Gambar 2. Es yang terbentuk dari aktivitas bakteri INA pada daun Jeruk keprok soe dalam microtube. Keterangan: Kode Isolat (a) dan (e) Kontrol, (b) AH1, (c) AH6, (d) BH3, (f) $\mathrm{BH} 5$, (g) $\mathrm{CH} 2$, dan (h) $\mathrm{CH} 3$

Sampel yang mengalami pembekuan diduga akibat dari aktivitas bakteri INA, hasil ini menunjukan bahwa Koloni yang dapat dikategorikan sebagai positif bakteri INA adalah koloni yang memiliki aktivitas nukleasi es. Aktivitas nukleasi es dapat terlihat ketika suspensi bakteri yang berada di dalam microtube membeku setelah diuji pada suhu $-5^{\circ} \mathrm{C}$ selama 3 menit. Hal ini menunjukan microtube yang berisi suspensi tersebut terdapat bakteri INA yang memiliki protein tunggal sebagai penginisiasi pembentukan inti es (Hill et al. 2014). Sebaliknya, jika suspensi bakteri tersebut tidak membeku, maka suspensi tersebut dikategorikan sebagai negatif bakteri INA.
Berdasarkan hasil diatas maka dapat dilihat bahwa isolat yang positif bakteri INA paling banyak dari stasiun 3 dengan ketinggian $2000 \mathrm{~m} \mathrm{dpl}$.

Aktivitas nukleasi dapat diketahui ketika suspensi bakteri diuji pada suhu yang berbeda yaitu $-5^{\circ} \mathrm{C}, \quad-7^{\circ} \mathrm{C}$ dan $-10^{\circ} \mathrm{C}$. pengujian pada suhu berbeda dilakukan karena tidak semua sampel pada masingmasing stasiun mengalami aktivitas pembekuan pada suhu yang sama (Susilowati et al.,2018). Perbedaan suhu tersebut disebabkan karena adanya perbedaan aktivitas pada masing-masing suspensi bakteri yang dilakukan pengujian. Hal tersebut tergantung pada aktivitas 
protein dari bakteri INA yang hidup pada daun. Hal tersebut menunjukan bahwa dalam setiap stasiun pengambilan sampel terdapat beberapa bakteri yang memiliki aktivitas yang berbeda-beda, bahkan dalam 1 stasiun.
Pada uji aktivitas nukleasi es yang dilakukan didapatkan hasil yaitu 2 sampel mengalami pembekuan pada suhu $-7^{\circ} \mathrm{C}$, sedangkan 6 sampel membeku pada suhu $-10^{\circ} \mathrm{C}$ (Tabel 4).

Tabel 4. Klasifikasi bakteri INA berdasarkan perbedaan suhu aktivitas nukleasi es

\begin{tabular}{ccc}
\hline Kode Isolat & Suhu Pembekuan & $\begin{array}{c}\text { Kelas Protein } \\
\text { INA }\end{array}$ \\
\hline $\mathrm{BH} 5$ & $-7^{\circ} \mathrm{C}$ & $\mathrm{B}$ \\
$\mathrm{CH} 3$ & $-7^{\circ} \mathrm{C}$ & $\mathrm{B}$ \\
$\mathrm{AH} 1$ & $-10^{\circ} \mathrm{C}$ & $\mathrm{C}$ \\
$\mathrm{AH} 6$ & $-10^{\circ} \mathrm{C}$ & $\mathrm{C}$ \\
$\mathrm{BH} 3$ & $-10^{\circ} \mathrm{C}$ & $\mathrm{C}$ \\
$\mathrm{CH} 2$ & $-10^{\circ} \mathrm{C}$ & $\mathrm{C}$ \\
$\mathrm{CH} 5$ & $-10^{\circ} \mathrm{C}$ & $\mathrm{C}$ \\
$\mathrm{CH} 7$ & $-10^{\circ} \mathrm{C}$ & $\mathrm{C}$ \\
\hline
\end{tabular}

Keterangan:

Kelas Protein INA B: Bakteri aktif pada suhu $\geq-5^{\circ} \mathrm{C}$ hingga $-7^{\circ} \mathrm{C}$

Kelas Protein INA C: Bakteri aktif pada suhu $\geq-7^{\circ} \mathrm{C}$ hingga $-10^{\circ} \mathrm{C}$

Berdasarkan uji yang dilakukan bakteri berupa pengamatan morfologi sel terdapat aktivitas nukleasi es dari isolat bakteri, ditemukan bahwa dua isolat bakteri tergolong dalam kelas B kedua isolat ini terdapat pada stasiun pengambilan sampel dengan ketinggian 1800. $\mathrm{m}$ dpl dan $2000 \mathrm{~m}$ dpl, sedangkan enam isolat bakteri lainya merupakan kelas $\mathrm{C}$ dengan ketinggian stasiun pengambilan sampel $1500 \mathrm{~m} \mathrm{dpl}$, $1800 \mathrm{~m}$ dpl dan $2000 \mathrm{~m}$ dpl. Jika dibandingkan dengan penelitian (Rajasa, 2015) yang memperoleh 6 Isolat bakteri positif bakteri INA dengan kelas Protein INA 1 isolat bakteri kelas B terdapat pada stasiun pengambilan sampel dengan ketinggian $1800 \mathrm{~m}$ dpl dan 5 Isolat bakteri kelas $\mathrm{C}$ dengan ketinggian stasiun pengambilan sampel $1800 \mathrm{~m}$ dpl sebanyak 2 isolat, $2000 \mathrm{~m} \mathrm{dpl}$ sebanyak 2 isolat dan $2500 \mathrm{~m}$ dpl sebanyak 2 isolat. Hal ini menunjukan bahwa penelitian yang dilakukan di Dataran Tinggi Mutis menunjukan aktivitas bakteri INA yang tinggi. dan jenis gram yang dapat dilihat dari hasil pewarnaan gram dari 8 isolat bakteri yang dilakukan menunjukan semua isolat merupakan bakteri Gram negatif yang ditandai dengan terbentuknya warna merah pada sel bakteri serta morfologi bentuk sel berupa batang.

Bakteri gram negatif memiliki komposisi dinding sel yang sebagian besar tersusun dari lapisan glikolipid yang sangat tipis, sehingga pada saat pewarnaan, kurang dapat mempertahankan zat warna utama ketika dicuci dengan alkohol, akibatnya kelompok bakteri ini memberikan kenampakan warna merah merupakan warna dari zat warna safranin (Murie et al., 2013). Hal ini sejalan dengan pendapat (Minsavage and Stall 2017), (Morris, et al., 2004)yang menyatakan bahwa aktivitas pembentukan inti es jelas terbatas pada spesies bakteri gram negatif, namun kehadiran spesiesspesies ini pada tanaman dan habitat alami yang lain merupakan suatu fenomena umum yang menarik.

\section{Karakter isolat yang Diperoleh}

Pengamatan mikroskopik isolat 


\section{SIMPULAN}

Penelitian dapat disimpulkan bahwa semakin tinggi tempat penggambilan pengambilan sampel, semakin banyak populasi bakteri yang didapat yaitu pada titik ketinggian $2000 \mathrm{~m}$ dpl diperoleh populasi bakteri sebesar $6,9 \times 10^{4}$, pada ketinggian $1800 \mathrm{~m}$ dpl banyaknya populasi bakteri yang ditemukan sebesar 6,3 x $10^{4}$ dan pada ketinggian $1500 \mathrm{~m}$ dpl jumlah populasi sebesar 5,4 x 103. Dan berdasarkan klasifikasi bakteri INA terhadap perbedaan suhu aktivitas es, diketahui bahwa bakteri INA yang menyerang daun Jeruk keprok soe yang ditemukan di Dataran Tinggi Mutis adalah bakteri INA kelas protein $\mathrm{B}$ yang mempunyai aktivitas pada suhu $-7^{\circ} \mathrm{C}$ dan $\mathrm{C}$ pada suhu $10^{\circ} \mathrm{C}$.

\section{UCAPAN TERIMA KASIH}

Disampaikan kepada Kementerian Riset, Teknologi, dan Pendidikan Tinggi Republik Indonesia yang telah mendanai Penelitian ini pada bidang Penelitian Dosen Pemula dengan nomor kontrak 0915/L8/KM/2019 dan Lembaga Penelitian dan Pengabdian Masyarakat (LPPM) Universitas Katolik Widya Mandira yang telah mendukung kelancaran penelitian ini.

\section{DAFTAR PUSTAKA}

A Susilowati1, L Y Oktiningtiyas and $\mathrm{R}$ Setyaningsih. 2018. "Enumeration of Ice Nucleation Active Bacteria and Severity of Frost Injury ( Embun Upas) on Potato in Enumeration of Ice Nucleation Active Bacteria and Severity of Frost Injury ( Embun Upas) on Potato in Wonosobo, Dieng Plateau." 4th International Conference on Agricultural and Biological Sciences: 185.

Adar, D., M. Bano, E.S. Woods, Wei, R. Mason, dan S. Singgih. 2013. "Selera Konsumen Terhadap Jeruk Keprok Soe Di Beberapa Kota Di Indonesia." Prosiding Seminar Nasional
Komunikasi Hasil-hasil Penelitian dan Pengkajian Pengembangan Jeruk keprok soe. Nusa Tenggara Timur: 21017.

Atlas, Ronald M. Handbook of MICROBIOLOGICAL MEDIA Fourth Edition.

Failor, K C, D G Schmale Iii, B A Vinatzer, and C L Monteil. 2017. "Ice Nucleation Active Bacteria in Precipitation Are Genetically Diverse and Nucleate Ice by Employing Different Mechanisms." 11(12): 2740-53. http://dx.doi.org/10.1038/ismej.2017.12 4.

Govindarajan, A. G., and S. E. Lindow. 2006. "Size of Bacterial Ice-Nucleation Sites Measured in Situ by Radiation Inactivation Analysis." Proceedings of the National Academy of Sciences 85(5): 1334-38.

Hardiyanto, C. Martasari, dan H. Mulyanto. 2017. "Analisis Keragaman Jeruk Keprok Indonesia Menggunakan Primer RAPD." Jurnal Hortikultura 3: 3:239246.

Hill, Thomas C. J. et al. 2014. "Measurement of Ice Nucleation-Active Bacteria on Plants and in Precipitation by Quantitative PCR." Applied and Environmental Microbiology 80(4): 1256-67.

Hirano, S. S., L. S. Baker, and C. D. Upper. 2008. "Ice Nucleation Temperature of Individual Leaves in Relation to Population Sizes of Ice Nucleation Active Bacteria and Frost Injury." Plant Physiology 77(2): 259-65.

Manandhar, D N et al. 2008. "Nutritional Assessment of Patients under Hemodialysis in Nepal Medical College Teaching Hospital." Nepal Medical College journal : NMCJ 10(3): 164-69. http://www.ncbi.nlm.nih.gov/pubmed/1 9253860 .

Minsavage, G V, and R E Stall. 2017. "IceNucleation-Active Bacteria on Citrus in Florida." Plant Pathogenic Bacteria pp 
994-1004 4(23): 994-95.

Missa, Hildegardis et al. "ACTIVE PADA JERUK KEPROK SOE DI DATARAN TINGGI MUTIS." : 403-7.

MISSA, HILDEGARDIS. 2016. "Diversity and Phylogenetic Relationship of Cellulolytic Bacteria from the Feces of Bali Cattle in South Central Timor, East Nusa Tenggara, Indonesia." Biodiversitas, Journal of Biological Diversity 17(2): 614-19.

Morris, C E, D G Georgakopoulos, and D C Sands. 2004. "Ice Nucleation Active Bacteria and Their Potential Role in Precipitation." 121: 87-103.

Murie $1 \mathrm{~J}$, Attard E, Sancelme M, Deguillaume L, Guilbaud C, Morr is C E, Amato P and Delort A M. 2013. "Ice Nucleation Activity of Bacteria Isolated from c Loud Water." J. Atmospheric Envir 70: 392-400.
Rajasa, A.K. 2015. "Isolasi Dan Identifikasi Bakteriice Nucleationactive (INA) Penyebab Embun Upas (Frost Injury) Pada Daun Tanaman Kentang (Solanum Tuberosuml.) Di Kecamatan Batur, Dataran Tinggi Dieng." Skripsi. UNSFMIPA Jur. Biologi-M0411009: M0411009.

Rostami, Mahdieh, Nader Hasanzadeh, Pejman Khodaygan, and Ali RiahiMadvar. 2018. "Ice Nucleation Active Bacteria from Pistachio in Kerman Province, Iran." : 51-58.

STEPHANIE, and DIANA ELIZABETH WATURANGI. 2012. "Distribution of Ice Nucleation-Active (INA) Bacteria from Rain-Water and Air." HAYATI Journal of Biosciences 18(3): 108-12. http://dx.doi.org/10.4308/hjb.18.3.108. 